Bulletin of the Natural History Museum, 2015, 8: 87-100.

Received 26 Nov 2015; Accepted 15 Dec 2015.

doi: $10.5937 /$ bnhmb1508087J

UDC: 502.172:[502.211:582(497.11)

Original scientific paper

\title{
CONSERVATION STATUS OF SOME RARE BOREO-MONTANE SPECIES IN SERBIA
}

\author{
KSENIJA JAKOVLJEVIĆ ${ }^{1 *}$, MARJAN NIKETIĆ ${ }^{2}$, DMITAR LAKUŠIĆ ${ }^{1}$, \\ SNEŽANA VUKOJIČIĆ ${ }^{1}$ \\ ${ }^{1}$ Faculty of Biology, Institute of Botany and Botanical Garden "Jevremovac", \\ University of Belgrade, Takovska 43, 11000 Belgrade, Serbia, \\ e-mail": kjakovljevic@bio.bg.ac.rs \\ ${ }^{2}$ Natural History Museum, Njegoševa 51, 11000 Belgrade, Serbia
}

Abstract. Due to disjunct distribution and habitat specificity, boreo-montane species are particularly vulnerable to the declining in area and population size. Although great proportion of these species has been already included, certain number of rare species among them so far has not been protected by any national or international document. This paper reviews the distribution and conservation status of 13 rare boreo-montane taxa not covered by any act of protection yet. For each species, the IUCN threatened status in Serbia is given; on the basis of these estimates it is proposed for 10 of them to be included in further acts of protection.

Key words: IUCN threatened status, plant protection, rarity analysis

\section{INTRODUCTION}

Human activities have been recognized in the recent decades as a key factor of threats to biodiversity, especially knowing that about $83 \%$ of the Earth's land surface has been under the anthropogenic influence (Sanderson 
et al. 2002). Consequently, the number of species at extinction risk gets higher every year (Hughes et al. 1997; Chapin et al. 2000). Loss of habitats presents the most important reason of biodiversity downfall (Balmford et al. 2005). This process is particularly strong in narrow distributed species. It is known that rare species occur statistically more often among species that are at the limit of their geographical range, and their proportion is particularly high among the disjunct distributed species, as arctic-alpine and boreo-montane (Kull et al. 2002).

There are numerous definitions for rarity, mainly based on species geographical range, limited abundance or both parameters (Gaston 1997). However, with mapping of species distribution on grid maps rarity can be quantified, considering that based on number of squares that particular species occupies, it can be designated as common or rare. According to Hodgson (1986), who worked with $5 \times 5 \mathrm{~km}$ grid maps, species that appear in less than $20 \%$ of squares can be regarded "restricted", those that occur in more than 5\% are "uncommon", while as "rare" species are considered those that appear in less than $5 \%$ of grid squares.

Boreo-montane flora presents specific group of disjunctly distributed plant species, with the northern part of its range within the taiga region, while the southern part is mainly restricted to the mountains of central and southern Europe (Vukojičić et al. 2014). Due to habitat specificity and their endangerment, the great number of boreo-montane species is protected by European and national legislation. According to Vukojičić et al. (2014), $19 \%$ of the analyzed boreo-montane species are classified as threatened by the IUCN list (IUCN 2012a) and the European Red List (Bilz et al. 2011), and as threatened or extinct by the Red Book of the Flora of Serbia (Stevanović 1999). In addition, rare species analysis has shown that $84 \%$ or 52 analyzed boreo-montane species in Serbia are considered to be rare. However, although the significant part of this flora has been already protected by national and/or international documents, certain number of them remains unprotected. Namely, previous analyses (Vukojičić et al. 2014) showed that 13 rare boreo-montane species in Serbia have not been protected by any international lists (Bilz et al. 2011, IUCN 2012a), the Red Data Book of Flora of Serbia 1 (Stevanović 1999) or national legislation (SGRS 2010-2011), with no change even in the latest international lists (IUCN 2015). This fact was the signal for the further investigation and estimation of the threatened status for those potentially endangered species that should result in some form of protection.

\section{Material and methods}

In this paper we analyzed distribution and threatened status for some boreo-montane species determined as rare in the territory of Serbia, but still 
not protected by any document (Vukojičić et al. 2014). According to Hodgson (1986) species are considered to be rare if occur in less than 5\% of the grid squares. The distribution data are based on recent field studies, on the analysis of herbarium specimens deposited at BEOU, BEO, HMMNH (Thiers 2015) and HMD (Herbarium Moesiacum Doljevacunregistered collection of Novica and Vladimir Randjelović), as well as on critically evaluated literature records. The used nomenclature follows the Plant List Database (2013). Each species distribution was presented on 10 $\mathrm{km} \times 10 \mathrm{~km}$ grids based on the Universal Transverse Mercator projection (Lampinen 2001). The investigated area is encompassed by UTM Grid Zone 34T. For estimation of the threatened status of analyzed species on the territory of Serbia, IUCN criteria and categories, version 3.1 (IUCN 2012b) were used.

\section{RESULTS AND DISCUSSION}

\section{Allium schoenoprasum L. - Amaryllidaceae}

General distribution: boreal regions of Euroasia and North America.

Distribution in Serbia: E Serbia: Mt Stara Planina - Arbinje, Dojkino Vrelo, Govedarnik, Kopren, Krvave Bare, Midžor, Tupanar, Topli Do, Vražja Glava (FN49, FP20, FP30, FP40); SW Serbia: Pešter - Begov Lug, Boroštica Kanal, Čađavica, Suvi Do, Trojan, Zekića Brdo (DN26, DN36, DN37); Kosovo \& Metochia: Mt Prokletije Đeravica, Kurvala, Nedžinat (DN21, DN22, DN31), Mt Šar Planina - Durlov Potok, Rudoka, Stojkova Kuća-Durlov Potok, Stojkova Kuća-Jezerska Čuka (DM73, DM74, EM06, EM07). (Fig. 1)

Number of UTM squares (\%): 1.39

IUCN threatened status in Serbia: VU B1b(iii)+2b(iii)

\section{Carex canescens L. - Cyperaceae}

General distribution: North America, Asia, Europe southwards to the Pyrenees, Macedonia and C Ukraine.

Distribution in Serbia: $\underline{C}$ Serbia: Mt Kopaonik - Kadijevac, Karaman, Pajino Preslo, Suvo Rudište (DN79, DN89); W Serbia: Čačak - Tučkovo (DP36); SW Serbia: Mt Golija (DN49, DN59, DP40); NE Serbia: Đerdap Gorge - Mt Miroč (FQ03), Mt Malinik - Canyon of Lazareva river (EP77), Mt Veliki Krš - Strelinik (EP89); E Serbia: Mt Stara Planina - Arbinje, Babin Zub, Gornje Lise, Govedarnik, Kopren, Krvave Bare, Tri Čuke (FN49, FP30); SE Serbia: Grdelica Gorge (EN83, EN93, EN94), Vlasina Biljena Bara, Crkvena Mala, Gadžina Bistrica, Veliki Most - Stratorija (FN03, FN12, FN14); Kosovo \& Metochia: Mt Prokletije - Nedžinat (DN22), Mt Šar Planina Konjuška (DM96). (Fig. 2)

Number of UTM squares (\%): 1.89

IUCN threatened status in Serbia: VU B1a,b(iii,v)+2a,b(iii, c); C2a(i) 


\section{Carex panicea L. - Cyperaceae}

General distribution: Asia, North America, most of the Europe, but rare in the Mediterranean region.

Distribution in Serbia: Vojvodina: Mt Fruška Gora (CQ99, CR90, DQ09, DR00), Morović - surrounding (CQ58), Novi Sad - surrounding (DR01, DR11); Pomoravlie: Jagodina (EP26); C Serbia: Mt Goč - Gvozdac (DP72); W Serbia: Mt Tara - Mitrovac (CP76), Mt Zlatibor - Kraljeve Vode, Ribnica (CP93); SW Serbia: Mt Golija (DN49, DN59), Pešter - Karajukića Bunari (DN27), Sjenica - surrounding (DN19, DN29), Tutin Crniš, Dobrinje, Dubovo, Kočarnik, Pope, Štavica, Tutin (DN45, DN46, DN55), Mt Zlatar - Mokra Poljana peak (DP00); E Serbia: Niš (EN79); SE Serbia: Grdelica Gorge Grdelica (EN85), Pirot - Barje, Kostur, Rasnica, Sukovo (FN27, FN36), Vlasina - Bukova Glava (FN12); S Serbia: Vranje (EN71); Kosovo \& Metochia: Mt Šar Planina Stojkova Kuća - Durlov Potok, Stojkova Kuća - Piribeg (EM06). (Fig. 3)

Number of UTM squares (\%): 2.68

IUCN threatened status in Serbia: VU B1a,b(iii)+2a,b(iii); C2a(i)

\section{Eriophorum angustifolium Honck. - Cyperaceae}

General distribution: Most of Europe, but absent from much of the Mediterranean region and the south-east Sibir, N Mongolia, Manchuria, Korea, North America, South Africa.

Distribution in Serbia: Vojvodina: Mt Fruška Gora - Ratno ostrvo (DR11); $\underline{\mathrm{C}}$ Serbia: Mt Goč - Gvozdac (DP72), Mt Kopaonik - Gorge of the Samokovska river, Jankova Bara, Krst, Pajino Preslo, Suvo Rudište (DN89); W Serbia: Mt Tara Šljivovica (CP86), Mt Zlatibor - Negbine (DP02); SW Serbia: Pešter - Karajukića Bunari (DN27); NE Serbia: Mt Stol (EP99); E Serbia: Mt Stara Planina - Arbinje, Babin Zub, Bolvan, Bratkova Strana, Dojkinačka river, Ivankovica, Jelovička river, Kopren, Krvave Bare, Midžor, Ponor, Ravno Bučje, Srejnica, Tri Čuke, Vražja Glava (FN48, FN49, FP20, FP21, FP30, FP40); SE Serbia: Grdelica Gorge (EN83, EN93, EN94), Mt Ostrozub (FN04), Vlasina - Biljena Bara, Brana, Bratanov Del, Crkvena Mala, Duga Zanoga, Gadžina Bistrica, Okruglica, Veliki Most - Stratorija, Vlasina Rid, Vlasinsko Blato (FN02, FN03, FN12, FN14); S Serbia: Vranje - surrounding (EN71, EN72); Kosovo \& Metochia: Koritnik (DM65, DM66), Mt Prokletije - Nedžinat (DN22), Mt Šar Planina - Durlov Potok, Mala Vraca, Prizrenska Bistrica, Rudoka, Šutman, Velika Vraca, Tija voda (DM73, DM74, DM96, EM07). (Fig. 4)

Number of UTM squares (\%): 2.98

IUCN threatened status in Serbia: VU B1b(iii)+2b(iii)

\section{Eriophorum vaginatum L. - Cyperaceae}

General distribution: Asia, North America, N \& C Europe extending southwards locally, and mainly in the mountains, to S. Spain, N. Italy and Republic of Macedonia.

Distribution in Serbia: Kosovo \& Metochia: Mt Šar Planina - Šutman, Velika Vraca (Tija voda) (DM73, DM74). (Fig. 5)

Number of UTM squares (\%): 0.20

IUCN threatened status in Serbia: EN B1a 


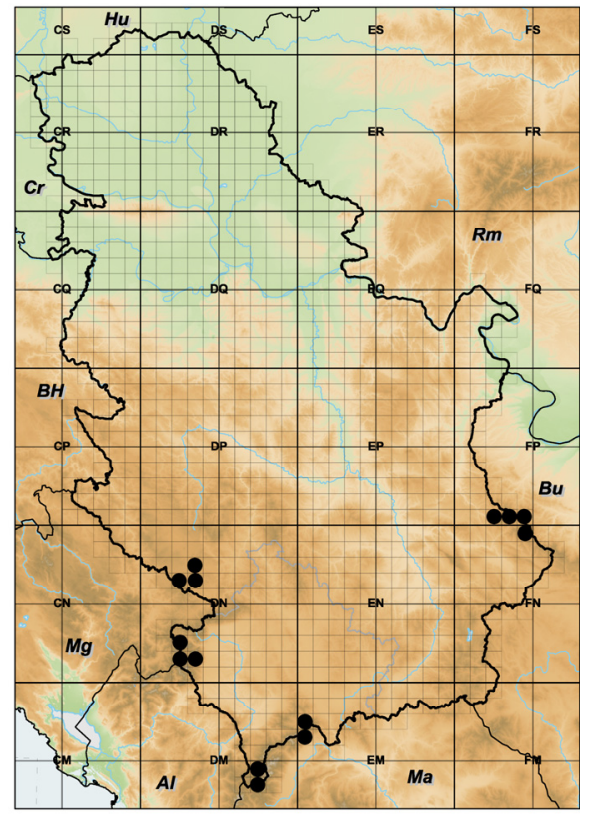

Fig. 1. - Distribution of Allium schoenoprasum L. in Serbia.

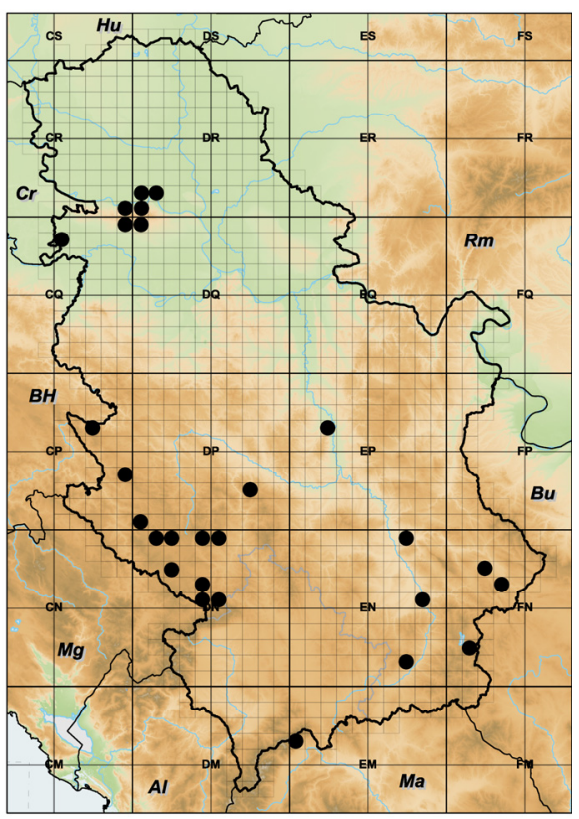

Fig. 3. - Distribution of Carex panicea L. in Serbia.

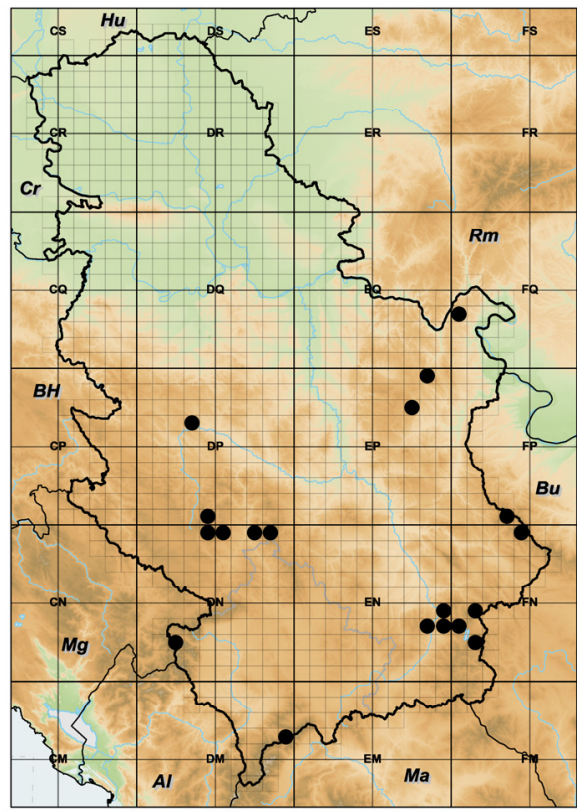

Fig. 2. - Distribution of Carex canescens L. in Serbia.

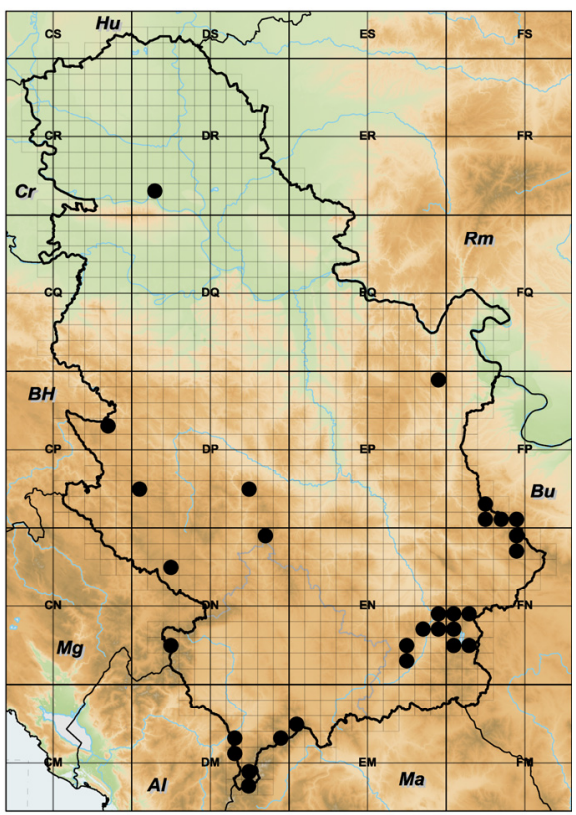

Fig. 4. - Distribution of Eriophorum angustifolium Honck. in Serbia. 


\section{Gymnocarpium dryopteris (L.) Newman - Cystopteridaceae}

General distribution: boreal regions of Euroasia and North America.

Distribution in Serbia: Vojvodina: Mt Fruška Gora - Iriški venac (DR00), Novi Sad - surrounding (DR01, DR11); Šumadija: Mt Rudnik (DP68), C Serbia: Mt Goč Gvozdac, Sokolja (DP72), Mt Kopaonik - Bećirovac, Hajdučki Potok (DN89); NW Serbia: Loznica - Paskovac, Podrinje (CQ52), Zvorničko Jezero - Drinjača (CQ50); $\underline{\text { W }}$ Serbia: Mt Kulaja Planina - Lise (DP33), Mt Tara - Beli Rzav, Derventa, Grlac, Rača (CP66, CP75, CP86), Mt Zlatibor (CP93); SW Serbia: Mt Zlatar - Golo Brdo, Mokra Poljana (DP00); NE Serbia: Mt Rtanj (EP64, EP74); E Serbia: Knjaževac (FP10), Mt Stara Planina - Arbinje, Babin Zub, Sveti Nikola - Orlova Stena (FN49, FP21, FP30), Mt Suva Planina (EN98); SE Serbia: Mt Čemernik - Cvetkova river (FN03), Mt Ostrozub - Čobanac, Ruplje (EN94, FN04), Vlasina - Bukova Glava, Crkvena Mala, Gorge of Lisinska river, Mali Most (FN03, FN11, FN12); Kosovo \& Metochia: Mt Prokletije Bogićevica, Dečani, Derviš Kom, Kožnjar, Kurvala, Nedžinat, Prilepske Planine (DN21, DN22, DN23, DN31, DN32), Mt Koritnik - Rapča (DM65, DM66), Mt Šar Planina - Bistra, Brezovica, Konjuška, Piribeg, Stojkova Kuća, Stojkova Kuća-Piribeg (DM96, DM97, EM06). (Fig. 6)

Number of UTM squares (\%): 3.58

IUCN threatened status in Serbia: LC

\section{Gymnocarpium robertianum (Hoffm.) Newman - Cystopteridaceae}

General distribution: boreal and temperate regions of Euroasia and North America.

Distribution in Serbia: NW Serbia: Loznica - Paskovac (CQ52); W Serbia: Mt Mokra Gora (CP84), Mt Tara - Beli Rzav river, Crvene Stene, Čemerište, Derventa river canyon, Karaula Štula, Perućac, Perućac - Derventa, Sečuj - Ljuti Breg (CP66, CP75, CP76); SW Serbia: Prijepolje - Canyon of Mileševka river (CP90); Kosovo \& Metochia: Mt Koritnik (DM65, DM66), Mt Prokletije - Bogićevica, Koprivnik (DN21, DN22, DN23, DN31, DN32, DN54), Mt Šar Planina - Ljuboten, Piribeg (EM06, EN07, EN17). (Fig. 7)

Number of UTM squares (\%): 1.69

IUCN threatened status in Serbia: LC

\section{Moneses uniflora A. Gray - Pyrolaceae}

General distribution: Most of Europe, but absent from many of the islands and the extreme south.

Distribution in Serbia: C Serbia: Mt Kopaonik - Barska river, Crni Jelak, Gobelja, Kukavica, Lisina, Metođe, Novoselske Bačije, Pašino Bačište (DN79, DN89); W Serbia: Mt Tara - Crvene Stene, Ivica, Mitrovac, Rzav (CP66, CP75, CP76), Mt Zlatibor - Tornik (CP93); SW Serbia: Mt Golija (DN49, DN59); E Serbia: Mt Stara Planina - Belan, Ravno Bučje, Sveti Nikola, Vrtop (FN49, FN58, FP21); Mt Suva Planina - Trem, Smrdan (EN98); $\underline{\text { SE }}$ Serbia: Mt Ostrozub (FN04); Kosovo \& Metochia: Mt Prokletije - Đeravica, Koprivnik, Košutane, Maja Rops - Babaloć - Kožnjar, Mokra Gora (DN20, DN21, DN23, DN31, DN32, DN44, DN54), Mt Koritnik (DM65, DM66), Mt Šar Planina - Kodža Balkan, Ošljak (DM87, DM97). (Fig. 8)

Number of UTM squares (\%): 2.29

IUCN threatened status in Serbia: EN B2b(iii) 


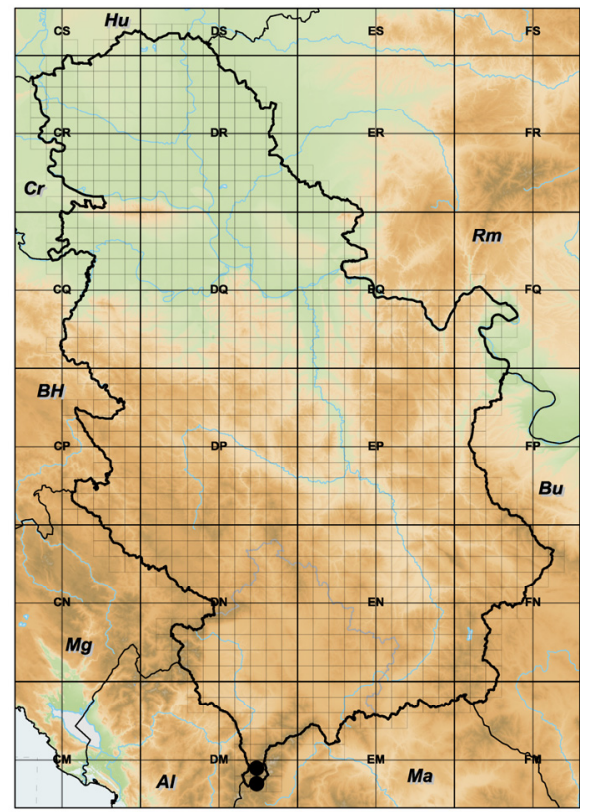

Fig. 5. - Distribution of Eriophorum vaginatum $\mathrm{L}$. in Serbia.

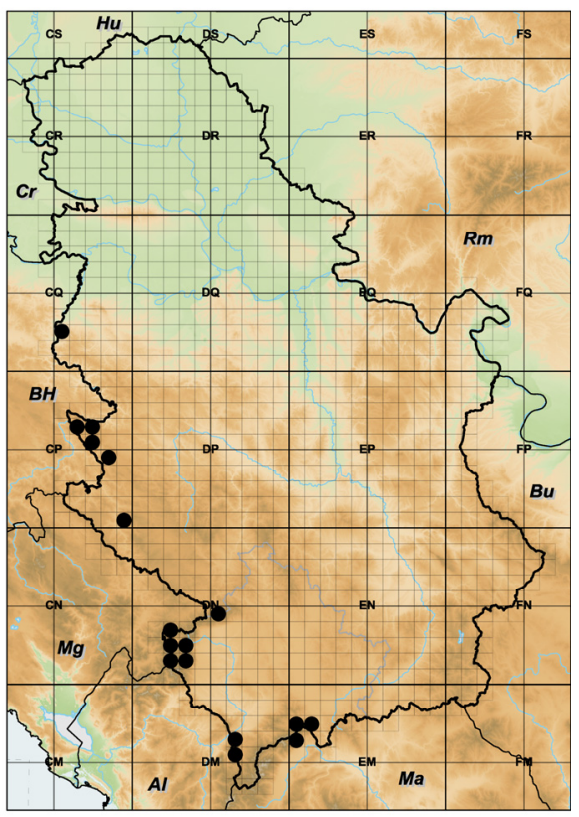

Fig. 7.-Distribution of Gymnocarpium robertianum (Hoffm.) Newman in Serbia.

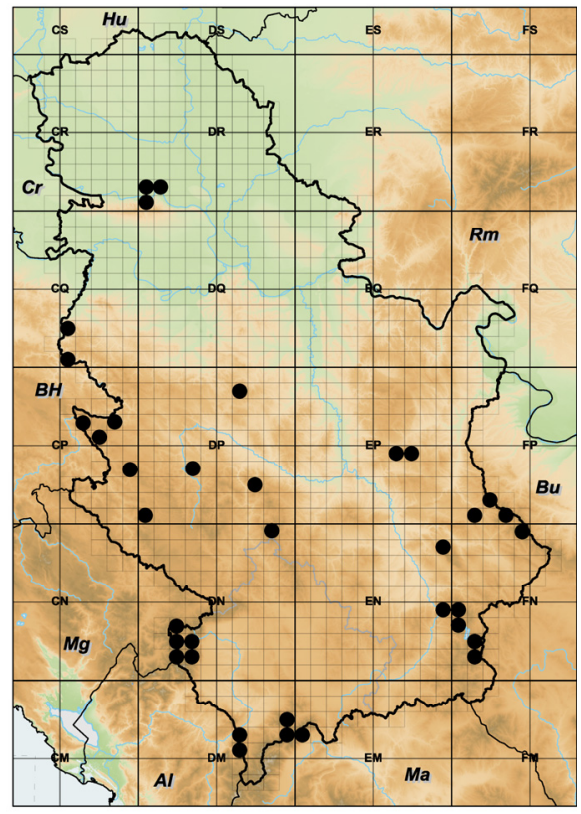

Fig. 6. - Distribution of Gymnocarpium dryopteris (L.) Newman in Serbia.

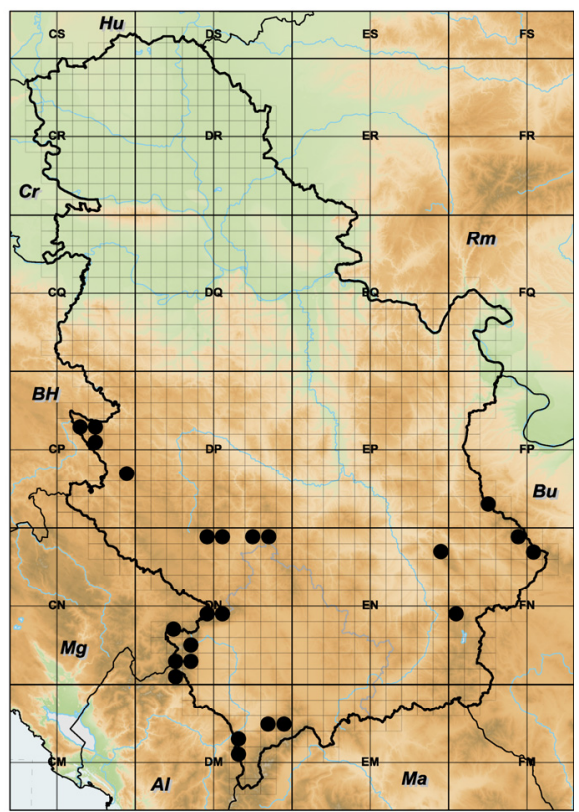

Fig. 8. - Distribution of Moneses uniflora A. Gray. in Serbia. 


\section{Orthilia secunda (L.) House - Pirolaceae}

General distribution: Most of Europe, but rare in the Mediterranean region, Asia, Sibir, North America.

Distribution in Serbia: Vojvodina: Deliblatska Peščara Sand - Grebenac, Kremenjak (EQ17), Mt Fruška Gora - Venac (DR00); C Serbia: Mt Goč - Gvozdac (DP72), Mt Kopaonik - Barska river, Čelinac, Gobelja, Gorge of Samokovska river, Krčmar, Kukavica, Metođe (DN79, DN89), Mt Stolovi - Orlovac (DP72); NW Serbia: Mt Maljen - Crni Vrh (DP28); W Serbia: Mt Tara - Crvene Stene, Kremna, Mitrovac (CP66, CP75, CP76, CP85); SW Serbia: Mt Golija (DN49, DN59), Raška - Zimovnik (DN69), Mt Zlatar (DP00); S Serbia: Mt Rudina (FN14), E Serbia: Knjaževac - Rasovati Kamen (FP22), Mt Stara Planina - Belan, Dojkinačka river (FN48, FN49), Mt Suva Planina Kosmovac, Trem, Smrdan (EN98, FN07, FN08); SE Serbia: Čemernik (FN03), Mt Ostrozub (FN04), Vlasina - Murje (FN03); Kosovo \& Metochia: Mt Prokletije Đeravica, Koprivnik, Koritnik, Lumbardska Planina, Marijaš, Mokra Gora, Nedžinat, Prilepske Planine (DM65, DM66, DN20, DN21, DN22, DN31, DN32, DN44), Mt Šar Planina - Bistrica, Kokošinje, Ošljak (DM87, DM96, DM97, EM07). (Fig. 9)

Number of UTM squares (\%): 3.48

IUCN threatened status in Serbia: VU B1a,b(iii)+2a,b(iii)

\section{Stellaria uliginosa Murray - Caryophyllaceae}

General distribution: Most of Europe northwards to Norway, but rare in the east and only on mountains in the south Europe, temperate regions of Asia, India, North America.

Distribution in Serbia: Vojvodina: Mt Fruška Gora - Kamenički Park (DR00), Obedska Bara (DQ15, DQ25); C Serbia: Mt Čemerno (DP52), Mt Kopaonik - Gobelja, Karaman, Krst, Metođe, Milanov Peak, Semeteš, Suvo Rudište-Sedlo, Vučjak (DN79, DN88, DN89); W Serbia: Mt Tara - Mitrovac (CP76), Mt Zlatibor (CP83, CP93); SW Serbia: Mt Golija (DN49, DN59), E Serbia: Mt Stara Planina: Kopren, Krvave Bare, Ravno Bučje (FN49, FP21); SE Serbia: Vlasina - Biljena Bara, Vardenik, Veliki Most - Stratorija (FN01, FN02, FN12, FN14); Kosovo \& Metochia: Mt Prokletije - Lumbardska Planina (DN22, DN32), Mt Šar Planina - Livadica, Ljuboten, Ošljak (DM97, EM07, EM17). (Fig. 10)

Number of UTM squares (\%): 2.29

IUCN threatened status in Serbia: VU B1a,b(iii)+2a,b(iii)

\section{Vaccinium uliginosum L. - Ericaceae}

General distribution: N \& C Europe, Asia, North America, Greenland.

Distribution in Serbia: C Serbia: Mt Kopaonik - Karaman, Ledenica, Nebeske Stolice, Suvo Rudište, Treska (DN88, DN89); E Serbia: Mt Stara Planina - Babin Zub, Dojkinačka river, Ivanova Livada, Kopren - Tri Čuke, Midžor, Stara Karaula, Stražna Čuka - Kopren, Tri Čuke, Tupanar, Vražja Glava, Žarkova Čuka (FN48, FN49, FP21, FP30, FP40); SE Serbia: Vlasina - Vardenik (FN01, FN02); Kosovo \& Metochia: Mt Šar Planina - Bistrica, Crni Vrh, Devedenica, Durlov Potok, Gine Vode, Gine Vode Mekuš Bor - Careve Livade, Gornja Šija, Kobilica, Konjuška, Livadica, Ljuboten, Mali Vrh, Piribeg (DM86, DM96, EM06, EM07). (Fig. 11)

Number of UTM squares (\%): 1.29

IUCN threatened status in Serbia: LC 


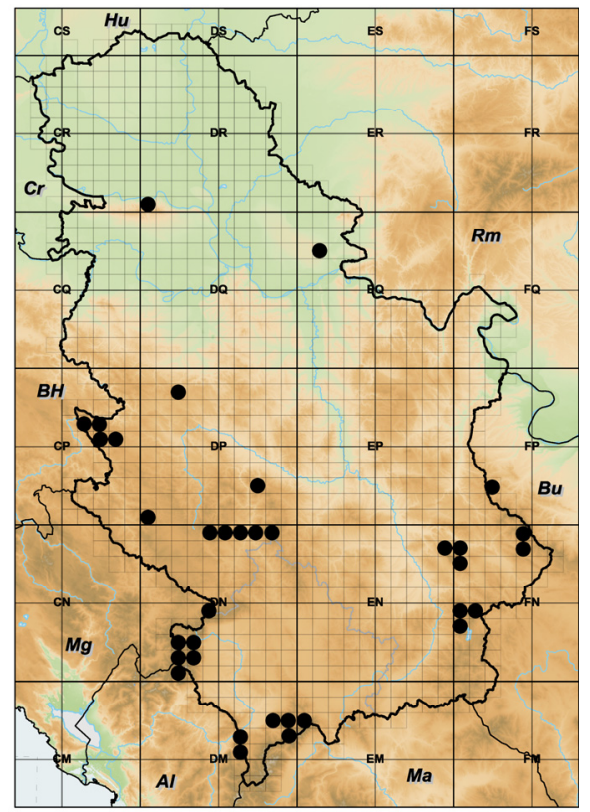

Fig. 9. - Distribution of Orthilia secunda (L.) House in Serbia.

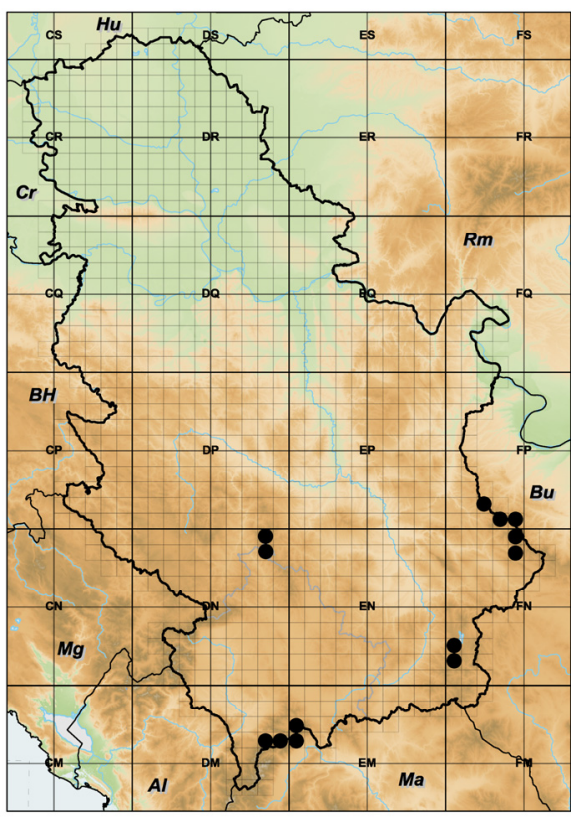

Fig. 11. - Distribution of Vaccinium uliginosum L. in Serbia.

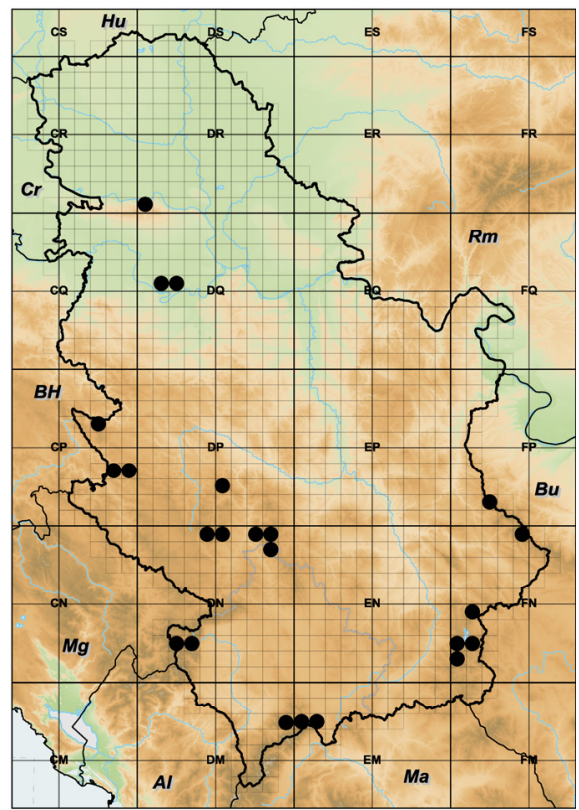

Fig. 10. - Distribution of Stellaria uliginosa Murray in Serbia.

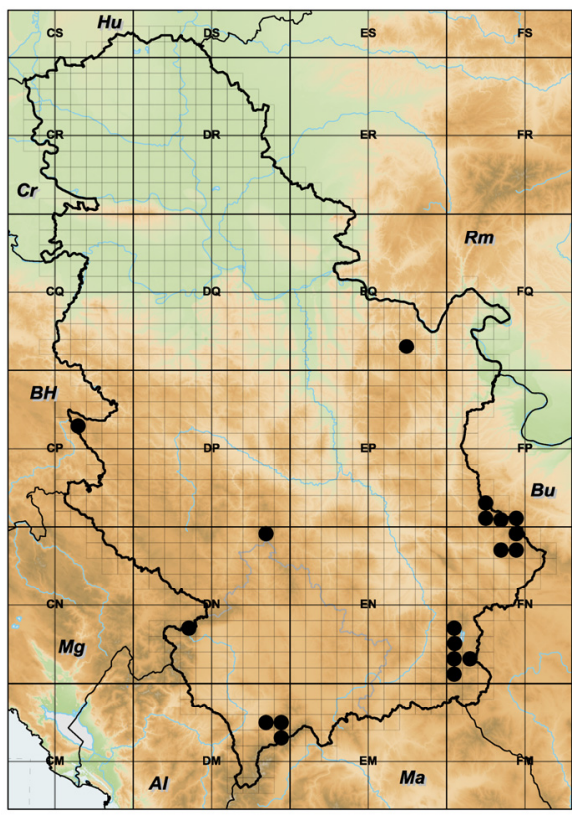

Fig. 12. - Distribution of Vaccinium vitis-idaea $\mathrm{L}$. in Serbia. 


\section{Vaccinium vitis-idaea L. - Ericaceae}

General distribution: Europe, Asia, North America, Greenland.

Distribution in Serbia: $\underline{C}$ Serbia: Mt Kopaonik - Pajino Preslo (DN89); $\underline{W}$ Serbia: Mt Tara - Rastište (CP66); SE Serbia: Majdanpek - surrounding (EQ71); E Serbia: Mt Stara Planina - Arbinje, Babin Zub, Bratkova strana, Čungulj, Dojkinačka river, Golčin Trap, Gornje Lise, Jelovička river, Kopren, Krvave Bare, Midžor, Stara Karaula, Stražna Čuka, Sveti Nikola - Orlova Stena, Tri Čuke - Tri Kladenca, Tupanar, Vražja Glava, Žarkova Čuka (FN48, FN49, FP20, FP21, FP30, FP40); SE Serbia: Mt Besna Kobila (FN00, FN01), Bosilegrad - surrounding (FN11), Mt Čemernik (FN03), Pirot - surrounding (FN38), Vlasina - Lisinska river, Vardenik (FN01, FN02, FN11); Kosovo \& Metochia: Mt Prokletije - Žljeb (DN33), Mt Šar Planina - Ošljak (DM87, DM97), Konjuška (DM96). (Fig. 12)

Number of UTM squares (\%): 1.89

IUCN threatened status in Serbia: VU B1b(iii) $+2 b$ (iii)

According to Vukojičić et al. (2014) thirteen rare species in Serbia so far have not been protected by any national document. Threatened status of these rare species estimated on the basis of IUCN criteria, indicate that 10 of them (included in CR, EN and VU categories) should be protected by national low. However, in our results conservation status of the species Botrychium matricariifolium is omitted considering that the results are consistent with those already obtained by Zlatković et al. (2009). According to the current IUCN categorization (2012b), status of Botrychium matricariifolium is evaluated as Critically Endangered (CR), considering the estimation of its extent of occurrence (less than $100 \mathrm{~km}^{2}$ ), and population with small number of individuals and with tendency of further declining (no subpopulation is estimated to contain more than 50 mature individuals and there are at least $90 \%$ of mature individuals in one subpopulation). This species appears only in one locality in Serbia (Mt Stara Planina), which also represents its southern borders in the distribution in Europe. Therefore it is considered to be facing an extremely high risk of extinction in the wild. However, despite the data given by Zlatković et al. (2009) explicitly indicate the need for protection, so far any measures have not been implemented.

Two species - Eriophorum vaginatum and Moneses uniflora are estimated as Endangered (EN), with estimated area of occupancy less than $500 \mathrm{~km}^{2}$ and continuity of declining in area, extent and / or quality of habitat. According to literature data, Eriophorum vaginatum can be found in Mts Kopaonik, Stara Planina, Šar Planina and Prokletije in Serbia. However, data on the presence of E. vaginatum on Mts Kopaonik and Stara Planina have not been confirmed by recent investigations (Mišić et al. 1978, Lakušić 1993), and for Mt Prokletije are imprecise. In addition, in any of the reviewed herbarium collection (BEOU, BEO, HMMNH, and HMD) there is no material that would confirm the existence of $E$. 
vaginatum in these mountains. Only reliable findings are related to Rudoka on Mt Šar Planina (Horvat 1952, Ranđelović et al. 1998) confirmed by corresponding herbarium material collected by Ranđelović and deposited in his private herbarium collection (HMD). Moneses uniflora, constituent of dark coniferous forests, is more frequent and can be found in Mts Kopaonik, Prokletije, Suva Planina, Šar Planina, Tara and Zlatibor.

The majority of the analyzed rare boreo-montane species (Allium schoenoprasum, Carex canescens, Carex panicea, Eriophorum angustifolium, Stellaria alsine, Vaccinium vitis-idaea, Orthilia secunda) is estimated as Vulnerable (VU) and therefore is considered to be facing high risk of extinction in wild. Most of these species are assessed as Vulnerable based on criterion B, i.e. geographic range characteristics.

Three species (Gymnocarpium dryopteris, Gymnocarpium robertianum and Vaccinium uliginosum) are listed as Least Concern (LC) since they do not meet criteria for critically endangered, endangered or vulnerable species.

Knowing the importance of habitat loss in biodiversity decreasing at local, regional and global scales (Dirzo \& Raven 2003, Balmford et al. 2005), the main reason for the continuous declining of geographic range and population size and consequently disappearance of boreo-montane species is the endangerment of their habitats, i.e. fragmentation, degradation and loss of mires and coniferous and coniferous-deciduous forests. One of the significant causes of changes detected in wetlands nowadays, as well as in most of the mire systems in rest of the Europe (Bragg \& Lindsay 2003), are human activities related mainly to water regime disturbing. This primarily refers to the peat extraction, drainage, inappropriate agricultural practice and pollution as universal influence. It is important to be aware that decline in population size presents the form of time lag between habitat loss and species loss (Brooks et al. 1999), and as decrease in number of mature individual is observed, immediate measures should be initiated by relevant institutions.

\section{CONCLUSION}

Conservation status of the 13 rare boreo-montane species in Serbia was analyzed: Allium schoenoprasum, Botrychium matricariifolium, Carex canescens, Carex panicea, Eriophorum angustifolium, Eriophorum vaginatum, Gymnocarpium dryopteris, Gymnocarpium robertianum, Moneses uniflora, Orthilia secunda, Stellaria uliginosa, Vaccinium uliginosum, Vaccinium vitis-idaea. From that list B. matricariifolium has already been proposed for protection as it was estimated as Critically Endangered (CR) 
species. It was found that two species (E. vaginatum and M. uniflora) are evaluated as Endangered (EN) and seven of them (A. schoenoprasum, $C$. canescens, $C$. panicea, E. angustifolium, $O$. secunda, S. uliginosa and $V$. vitis-idaea) are estimated as Vulnerable (VU). Three species (G. dryopteris, $G$. robertianum and $V$. uliginosum) are estimated as the Least Concern (LC).

The results obtained by our analyses, along with the fact that 39 rare boreo-montane species (75\% of rare boreo-montane species in Serbia) have already been protected on different level, indicate the importance of determining of rarity status in protection process. It should be mentioned the huge suitability of these analyses, since they are much faster and less demanding in comparison with IUCN criteria implementation. Therefore, we hope this will make rarity analysis as routine procedure in determining the need for protection of particular species.

\section{Acknowledgements}

The authors would like to thank Dr Vladimir Stevanović (University of Belgrade) who initiated our investigation of boreo-montane species in the Balkan Peninsula. We are also grateful to Dr Vladimir Ranđelović (University of Niš) for his help with distribution data. The Ministry of Education, Science and Technological Development of the Republic of Serbia, Project 173030 Biodiversity of the plant life of Serbia and Balkan Peninsula - Assessment, sustainable use and conservation (2011-2015), supported this research.

\section{REFERENCES}

Balmford, A., Bennun, L., Ten Brink, B., Cooper, D., Côté, I.M., Crane, P., Walther, B.A. (2005): The convention on biological diversity's 2010 target. Science 307: 212-213.

Bilz, M., Kell, S.P., Maxted, N., Lansdown, R.V. (2011): European red list of vascular plants. - Publications Office of the European Union, Luxembourg.

Bragg, O., Lindsay, R. (eds.) (2003): Strategy and action plan for mire and peatland conservation in central Europe. - Wetlands International, Wageningen.

Brooks, T.M., Pimm, S.L., Oyugi, J.O. (1999): Time lag between deforestation and bird extinction in tropical forest fragments. - Conservation Biology 13(5): 11401150 .

Chapin III, F.S., Zavaleta, E.S., Eviner, V.T., Naylor, R.L., Vitousek, P.M., Reynolds, H.L., Hooper, D.U., Lavorel, S., Sala, O.E., Hobbie, S.E., Mack, M.C., Diaz, S. (2000): Consequences of changing biodiversity. - Nature 105: 234-242. 
Dirzo, R., Raven, P.H. (2003): Global state of biodiversity and loss. - Annual Review of Environment and Resources 28: 137-167.

Gaston, K.J. (1997): What is rarity?. In: Kunin, W.E., Gaston, K.J. (ed.): The Biology of Rarity: 30-47. - Chapman \& Hall, London.

Hodgson, J.G. (1986): Commonness and rarity in plants with special reference to the Sheffield flora Part I: The identity, distribution and habitat characteristics of the common and rare species. - Biological Conservation 36(3): 199-252.

Horvat, I. (1952(1953)): Prilog poznavanju raširenja nekih planinskih biljaka u jugoistočnoj Evropi. - Godišnjak Biološkog Instituta u Sarajevu 5(1-2): 199-217.

Hughes, J.B., Daily, G.C., Ehrlich, P.R. (1997): Population diversity: its extent and extinction. - Science 278: 689-692.

IUCN (2012a): The IUCN red list of threatened species. Version 2012.2. [http:// www.iucnredlist. org]

IUCN (2012b): IUCN Red List Categories and Criteria: Version 3.1. Second edition. - Gland, Switzerland and Cambridge, UK: IUCN.

IUCN (2015): The IUCN Red List of Threatened Species. Version 2015-3. [http:// www.iucnredlist. org]

Kull, T., Kukk, T., Leht, M., Krall, H., Kukk, Ü., Kuusk, V. (2002): Distribution trends of rare vascular plant species in Estonia. - Biodiversity and Conservation 11: 171-196.

Lakušić, D. (1993): Visokoplaninska flora Kopaonika. - Biološki fakultet Univerziteta u Beogradu, Beograd. Magistarski rad (master's thesis, manuscr.)

Lampinen, R. (2001): Universal Transverse Mercator (UTM) and Military Grid Reference System (MGRS). [http://www.fmnh.helsinki.fi/english/botany/ afe/ map/utm.htm]

Mišić, V., Jovanović-Dunjić, R., Popović, M., Borisavljević, Lj., Antić, M., Dinić, A., Danon, J., Blaženčić, Ž. (1978): Biljne zajednice i staništa Stare planine. Srpska Akademija Nauka i Umetnosti, Beograd, Posebna izdanja 49: 1-389.

Ranđelović, V., Zlatković, B., Amidžić, L. (1998): Flora i vegetacija visokoplaninskih tresava Šar planine. - Zaštita prirode 50: 377-399.

Sanderson, E.W., Malanding, J., Levy, M.A., Redford, K.H., Wannebo, A.V., Woolmer, G. (2002): The human footprint and the last of the wild. - Bioscience 52: 891-904.

SGRS (2010-2011): Pravilnik o proglašenju i zaštiti strogo zaštićenih i zaštićenih divljih vrsta biljaka, životinja i gljiva. - Službeni Glasnik RS 5/2010, 47/2011.

Stevanović, V. (ed.) (1999): The Red Data Book of Flora of Serbia 1. Extinct and critically endangered taxa 1. - Ministry of Environment of the Republic of Serbia, Faculty of Biology, University of Belgrade, Institute for Protection of Nature of the Republic of Serbia, Belgrade.

The Plant List (2013): The Plant List, version 1.1. [http://www.theplantlist.org]

Thiers, B. (2015): Index Herbariorum: A global directory of public herbaria and associated staff. New York Botanical Garden's Virtual Herbarium. 
Vukojičić, S., Jakovljević, K., Matevski, V., Ranđelović, V., Niketić, M., Lakušić, D. (2014): Distribution, Diversity and Conservation of Boreo-Montane Plant Species in the Central Part of the Balkan Peninsula and the Southern Part of the Pannonian Plain. - Folia Geobotanica 49(4): 487-505.

Zlatković, B., Tomović, G., Ranđelović, V., Vukojičić, S., Niketić, M. (2009): Distribution and conservation status of several new and neglected vascular plants in Serbia. - Phytologia Balcanica 15(1): 95-105.

\title{
КОНЗЕРВАЦИОНИ СТАТУС НЕКИХ РЕТКИХ БОРЕО-МОНТАНИХ ВРСТА У СРБИЈИ
}

\author{
КСЕНИЈА ЈАКОВЉЕВИЋ, МАРЈАН НИКЕТИЋ, ДМИТАР ЛАКУШИЋ, \\ СНЕЖАНА ВУКОЈИЧИЋ
}

\section{Р Е 3 И М Е}

Услед свог дисјунктног распрострањења и специфичности станишта, борео-монтане врсте су нарочито осетљиве на смањење ареала и величине популација. Иако се значајан удео ових врста може сматрати ретким, одређени број до сада није заштићен ниједним домаћим или међународним документом. У овом раду се даје преглед распрострањења и конзервационог статуса 13 ретких борео-монтаних врста са подручја Србије које нису обухваћене ниједном мером заштите. За сваку врсту је дата процена статуса угрожености према IUCN-y, на основу чега је предложено да њих 10 буду стављене под заштиту. 